\title{
Aile Hekimliği Uygulamasının Bir Eğitim ve Araştırma Hastanesine Ayaktan Hasta Başvurularındaki Etkisi
}

\author{
Impact of Family Medicine Implementation in outpatient admissions in an education and research \\ hospital
}

\author{
Abdülkadir Aydın ${ }^{1}$, Yıldız Atadağ², Didem Kaya ${ }^{3}$, Hatice Dilber Köşker ${ }^{4}$, Fatih Başak ${ }^{5}$, Sema Uçak $^{6}$
}

Öz

Amaç: Türkiye'de Sağlıkta Dönüşüm Programı ile 2010 y1lı sonunda tüm yurt genelinde Aile Hekimliği Uygulamasına geçilmiştir. Bu çalışmada Aile Hekimliği Uygulamasının bir üçüncü basamak devlet hastanesinin ayaktan hasta başvurularına etkisinin değerlendirilmesi amaçlanmıştır. Yöntemler: Hastanemizin 2007-2014 yılları arasındaki ayaktan hasta başvuru sayıları otomasyon sistemi ile tarandı. Sağlık Bakanlığı, Tıpta Uzmanlık Kurulu'nun Aile Hekimliği asistan eğitiminde zorunlu rotasyon olarak belirlediği klinikler ve acil servis olmak üzere sekiz adet klinik incelendi. 2011 yılı Aile Hekimliği sistemi uygulama başlangıcı olarak alındı. 2007-2010 yılları arası Aile Hekimliği Uygulaması öncesi dönem, 2010-2014 yılları arası Aile Hekimliği Uygulaması sonrası dönem olarak ele alındı. İstanbul Anadolu yakası nüfus değişimleri düzeltmesiyle bağıntılı olarak dönemler arası başvurular karşılaştırıldı. Verilerin analizinde tanımlayıcı istatistikler, sürekli değişkenler için ortalama ve standart sapma, ölçüm değerlerinin normal dağılım göstermeyen karşılaştırmalarında Mann Whitney $U$ Test kullanıldı. Anlamlılık $\mathrm{p}<0,05$ düzeylerinde değerlendirildi.

Bulgular: İncelemeye alınan klinikler arasından göğüs hastalıkları ve kardiyoloji kliniklerine başvuran hasta sayılarında nüfus artışına oranla anlamlı bir artış olmadığı görülmüştür. Diğer kliniklerde ise başvuru sayıları nüfus artışıyla bağıntılı bir şekilde artmaktadır.

Sonuç: Aile Hekimliği Uygulaması üçüncü basamak hastaneler üzerinde başlangıç için olumlu etkiler oluşturmuştur. Bu etkinin daha da arttırlabilmesi için hastaların aile hekimlerine başvurmaları için teşvik edilmesi, yeterli sayıda birinci basamak sağlı elemanıyla sağlıkta sevk zincirinin uygulamaya alınması gerektiğini düşünüyoruz.

Anahtar Kelimeler: Aile hekimliği uygulamasi, sevk sistemi, basamak

\section{Abstract}

Aim: With the health transformation program in Turkey, the Family Medicine Implementation (FMI) was started across the nation in the end of 2010. This study attempted to assess the influence of the FMI on outpatient applications to a third level state hospital.

Methods: The number of outpatient applications from 2007 to 2014 was screened through an automation system. Eight clinics were examined including the clinics which Ministry of Health, the Board of Medical Specialties assigned as a part of obligatory rotation within the scope of Family Medicine assistant training, and emergency service. The year 2011 was taken as beginning year of the Family Medicine system. The period from 2007 to 2010 was taken as the pre-FMI period while the term from 2010 to 2014 was taken as the post-FMI period. The outpatient application rates of the selected clinics were compared by periods in correlation with population changes in the Anatolian site of İstanbul. In the analysis of the data, descriptive statistics, mean and standard deviation for continuous variables, Mann Whitney U Test for abnormal distribution comparisons of measured values were used. Significance was assessed at $p<0,01$ and $p<0,05$ levels.

Results: It was found that no significant increase occurred in the number of patients who applied to the clinics of chest diseases and cardiology in parallel to population growth. In other clinics, the number of applications increased in correlation with population growth

Conclusion: The family medicine implementation made positive effects on the third level hospital in the beginning phase. We are of the opinion that, in order for these positive effects to be improved further, patients should be encouraged to apply to family physicians, and a health referral chain should be implemented with sufficient numbers of primary care personnel.

Keywords: Family medicine, general practitioner, referral chain
${ }^{1}$ İstanbul Ümraniye Adem Yavuz Aile Sağlığı Merkezi, Aile Hekimliği, İstanbul, Türkiye. Istanbul Umraniye Adem Yavuz Family Health Center, Istanbul, Turkey.

${ }^{2}$ Gaziantep Şahinbey Bağlarbaşı Aile Sağlı̆ı Merkezi, Aile Hekimliği, Gaziantep, Türkiye. Gaziantep Baglarbasi Family Health Center, Gaziantep, Turkey.

${ }^{3}$ İstanbul Üsküdar 23 nolu Aile Sağlığı Merkezi, Aile Hekimliği, İstanbul, Türkiye.

Istanbul Uskudar 23. Family Health Center, Istanbul, Turkey

${ }^{4}$ Ümraniye Eğitim ve Araştırma Hastanesi, Aile Hekimliği, İstanbul, Türkiye.

Umraniye Education Research Hospital, Family Health, Umraniye, Istanbul, Turkey.

${ }^{5}$ Ümraniye Eğitim Araştırma Hastanesi, Genel Cerrahi, İstanbul, Türkiye.

Umraniye Education Research Hospital, General Surgery, Umraniye, Istanbul, Turkey.

6 Ümraniye Eğitim Araştırma Hastanesi, Ị̇ Hastalıkları Kliniği, İstanbul, Türkiye.

Umraniye Education Research Hospital, Internal Medicine Clinic, Istanbul, Turkey.

Etik Kurul: Calıșmanın lokal etik kurul onayı alınmıștır. Ethical approval: The study was approved by the local research ethics committee.

Çıkar Çatı̣mması: Yazarlar çıkar çatıșması

bildirmemişlerdir.

Conflict of Interest: No conflict of interest was declared by the authors.

Finansal Destek: Yazarlar bu olgu için finansal destek almadıklarını beyan etmişlerdir.

Financial Disclosure: The authors declared that this case has received no financial support.

Geliş Tarihi / Received

24.07.2017

Kabul Tarihi / Accepted

11.09.2017

Yayın Tarihi / Published

01.12.2017

Sorumlu yazar / Corresponding author

Abdülkadir Aydın

Adres/Address: Adem Yavuz mah. Eski Üsküdar Yolu cad.

No:1 Ümraniye, İstanbul, Türkiye.

Tel: +905324308624

E-posta: drabkay@gmail.com

C Copyright 2017 ACEM 


\section{Giriş}

Çağdaş sağlık sistemlerinin öncelikli amaçları arasında, birinci basamak sağlık hizmetlerine ağırlık vererek, sağlık hizmetlerine ulaşılabilirliği ve bu hizmetlerden herkesin ihtiyacı oranında yararlanmasını sağlamak ve böylece kişilerin yaşam kalitelerini ve sağlık standartlarını yükseltmek yer almaktadır [1].

Sağlik hizmeti sunumunda, hizmetten yararlanan bireylerin memnuniyeti önemlidir. Birinci basamak sağllk hizmetlerinin sürekli eğitimle geliştirilmesi ve güçlendirilmesi, çalışan hekimler ile diğer sağlık elemanlarının özendirilmesi, birey ihtiyaçlarının göz önünde bulundurularak koruyucu sağlık hizmetlerine ağırlık verilmesi ve kabul edilebilir sevk sisteminin uygulanması ana ilkelerdir. Bu ilkelerin hayata geçirilmesi ikinci ve üçüncü basamakta yığılmayı engelleyecek ve gerçekten bu basamaklarda tedavi edilmesi gereken hastalara yeterince zaman ayrılmasını sağlayacaktır. Birinci basamak sağlık hizmetlerinin etkili bir şekilde verilebilmesi, toplumun hastalık yükünü azaltmasının yanı sıra, ikinci ve üçüncü basamak tedavi kuruluşlarımızın da daha iyi ve kaliteli sağlık hizmeti ve sağlık eğitimi vermelerine firsat tanıyacaktır [2].

Aile Hekimliği Uygulaması (AHU) sevk zincirinde önemli oranda başarı sağlar. Hastalıkların uygun basamaklarda ele alınmasını ve tedavisini mümkün hale getirir. Sevk gerektiğinde, kişinin sağlık bilgileriyle birlikte doğru uzmanlık dalına ve doğru merkeze gitmesini sağlayarak, yüksek maliyetli ikinci ve üçüncü basamak sağlık hizmetlerinin daha etkili ve ekonomik biçimde kullanımını sağlar. Bu açıdan aile hekimliğ aynı zamanda birçok yanlış yönlendirmeyi, düzensizliği, gereksiz sağlık harcamasını, ikinci ve üçüncü basamakta gereksiz yığılmayı, kuyrukları ve hasta mağduriyetini engeller [3, 4].

AHU ile ikinci ve üçüncü basamak sağlık kuruluşlarındaki gereksiz yığılmanın önüne geçilip geçilmediği konusu çok çalışılmış bir konu değildir. Bu çalışmada AHU'nun üçüncü basamak sağlı kuruluşundaki ayaktan hasta başvuru sayılarına yansımasını değerlendirdik.

\section{Gereç ve Yöntemler}

Retrospektif gözlemsel bir çalışma planlandı. Çalışma Helsinki dekorasyonuna uygun olarak yapıldı. Çalışma protokolü hastane yerel etik kurulu tarafindan onaylandı (UEAH26.08.2015/12561). Hastanemiz kliniklerine ayaktan başvuran hasta sayıları hastane otomasyon sistemi üzerinden elde edildi. Nüfus verilerinin değerlendirmesi için hastanenin yerleşkesi nedeniyle Türkiye İstatistik Kurumundan alınan İstanbul Anadolu yakası nüfus verileri temel alındı. Aile hekimliği uzmanlık eğitiminde Tıpta Uzmanlık kurulu tarafından belirlenmiş zorunlu rotasyon yapılan yedi adet klinik (İç Hastalıkları, Pediatri, Genel Cerrahi, Kadın Hastalıkları ve Doğum, Psikiyatri, Göğüs Hastalıkları ve Kardiyoloji) ve Acil Servis olmak üzere sekiz adet branş üzerinden değerlendirme yapild1.

Değerlendirme dönemi olarak AHU öncesi ve sonras1 olarak iki dönem seçildi. İstanbul'da AHU'ya 2010 yılı ekim ayı sonunda geçilmiştir. AHU başlangıcı iki aylık geçiş dönemi göz önüne alınarak 2011 yılı olarak alındı. AHU öncesi dönem $2007-$ 2010 yılları arası dört yıllık periyot olarak alınmış olup, AHU sonrası dönem 2011-2014 yılları arası dört yıllık periyot olarak alındı. Sekiz klinik branş için nüfus düzeltmesine göre bağıntı ile iki dönem arasındaki değişiklikler hesaplandı.

İstatistik

Çalışmada elde edilen bulgular değerlendirilirken istatistiksel analizler için SPSS 22.0 (Statistical Package forthe Social Sciences, Power IBM Software) programı kullanıldı. Çalışma verileri değerlendirilirken tanımlayıcı istatistiksel metodların (Ortalama, Standart Sapma) yanı sıra ölçüm değerlerinin normal dağılım göstermeyen karşılaştırmalarında Mann Whitney U Test kullanıldı. Sayısal değişkenlerin ilişki karşılaştırmasında ise Spearman's Rho korelasyon testi kullanıld1. Anlamlılık $\mathrm{p}<0,01$ ve $\mathrm{p}<0,05$ düzeylerinde değerlendirildi.

\section{Bulgular}

AHU öncesi ve sonrası dönemde ilgili kliniklere yıllık ayaktan hasta başvuru sayıları ve bu dönemdeki nüfus değişimleri aşağıda tablo ve grafiksel anlatımla gösterilmiştir (Tablo 1) (Şekil 1-3).

AHU öncesi ve sonrası dönem karşılaştırıldığında acil servis $(\mathrm{p}=0,029)$, çocuk sağlı̆̆ ve hastalıkları $(\mathrm{p}=0,021)$, kadın hastalıkları ve doğum $(p=0,021)$, ruh ve sinir hastalıkları $(p=0,043)$ ve genel cerrahi $(p=0,027)$ kliniklerine başvuran hasta sayılarında artış gözlemlenmektedir. Nüfusun da artışı söz konusu olduğundan bu kliniklerdeki artış nüfusun artmasından kaynaklanmaktadır. Nüfus arttığı halde hasta sayıları aynı oranda artmayan gögüs hastalıkları $(\mathrm{p}=0,886)$, iç hastalıkları $(\mathrm{p}=0,770)$ ve kardiyoloji $(\mathrm{p}=0,248)$ kliniklerine başvuran hasta sayılarında anlamlı artış olmamıştır.

Tablo 1: Aile Hekimliği Öncesi ve Sonrası Kliniklerin Sayısal Başvuru Değişiklikleri.

\begin{tabular}{ccc}
$\begin{array}{c}\text { AHU Öncesi } \\
(2007-2010)\end{array}$ & $\begin{array}{c}\text { AHU Sonras1 } \\
(2011-2014)\end{array}$ & \\
\cline { 1 - 2 } $\begin{array}{c}\text { Ortalama } \pm \\
\text { Standart Sapma }\end{array}$ & $\begin{array}{c}\text { Ortalama } \pm \\
\text { Standart Sapma }\end{array}$ & \\
\hline $390901 \pm 92103$ & $594425 \pm 46568$ & 0,029
\end{tabular}

\section{Acil Servis}

ve Hastal

\begin{tabular}{|c|c|c|c|}
\hline Hastalıkları & $48694 \pm 27658$ & $106513 \pm 10802$ & 0,021 \\
\hline $\begin{array}{l}\text { Genel Cerrahi } \\
\text { Göğüs }\end{array}$ & $38411 \pm 8682$ & $58906 \pm 3077$ & 0,027 \\
\hline Hastalıkları & $38411 \pm 8682$ & $58906 \pm 3077$ & 0,886 \\
\hline $\begin{array}{l}\text { İç Hastalıkları } \\
\text { Kadın }\end{array}$ & $104911 \pm 25616$ & $117707 \pm 8923$ & 0,77 \\
\hline $\begin{array}{l}\text { Hastalıkları } \\
\text { ve Doğum }\end{array}$ & $52008 \pm 12524$ & $100831 \pm 9376$ & 0,021 \\
\hline Kardiyoloji & $6784 \pm 2617$ & $11110 \pm 5005$ & 0,248 \\
\hline
\end{tabular}
Göğüs

Ruh Sağlığ 1

ve

Hastalıkları $\quad 12640 \pm 1626 \quad 21226 \pm 6089 \quad 0,043$

Bir önceki fark testinde ortaya konan aile hekimliği öncesi ve sonrası hasta sayıları farklılığı nedeni olarak nüfus artışı konu edilmişti. Bu testte ise nüfus ile bağıntılı olan ve olmayan klinik hasta sayıları ortaya konulacaktır. Korelasyon katsayıları açısından anlamlı ilişkiler; acil servis $(\mathrm{p}=0,001)$, çocuk sağlığı ve hastalıkları $(p=0,001)$, kadın hastalıkları ve doğum $(p=0,004)$, iç hastalıkları $(p=0,207)$, ruh ve sinir hastalıkları $(p=0,001)$ ve genel cerrahi $(\mathrm{p}=0,001)$ kliniklerindedir. $\mathrm{Bu}$ kliniklere gelen hasta sayıları nüfusla bağıntılıolarak artmaktadır. Göğüs hastalıkları $(p=0,911)$ ve kardiyoloji $(p=0,289)$ kliniklerine başvuran hasta sayıları nüfus artışıyla aynı oranda artmamıştır.

\section{Tartışma}

Biz bu çalışmada AHU'nun ikinci ve üçüncü basamaklardaki yığılmanın önüne geçmesi beklentisinden yola çıkarak, bir üçüncü basamak devlet hastanesinde uygulama sonrası 
değişiklikleri değerlendirdik. İncelemelerimiz sonucunda AHU'nun iç hastalıkları, göğüs hastalıkları ve kardiyoloji kliniklerine ayaktan başvuran hasta sayıları üzerine başlangıç için azalma yönünde olumlu etkileri olduğu söylenebilir. Diğer kliniklerde (çocuk sağlığı ve hastalıkları, genel cerrahi, ruh ve sinir hastalıkları, kadın hastalıkları ve doğum, acil servis) ise anlamlı bir etki saptamadık. Fakat bu bulguları değerlendirirken toplumda sağlıkta farkındalığın artması ve sağlık hizmetlerine ulaşımın kolaylaşması gibi diğer etkileyici faktörlerinde göz önünde bulundurulması ve bu alanda daha kapsamlı araştırmaların yapılması gerektiğini düşünüyoruz.

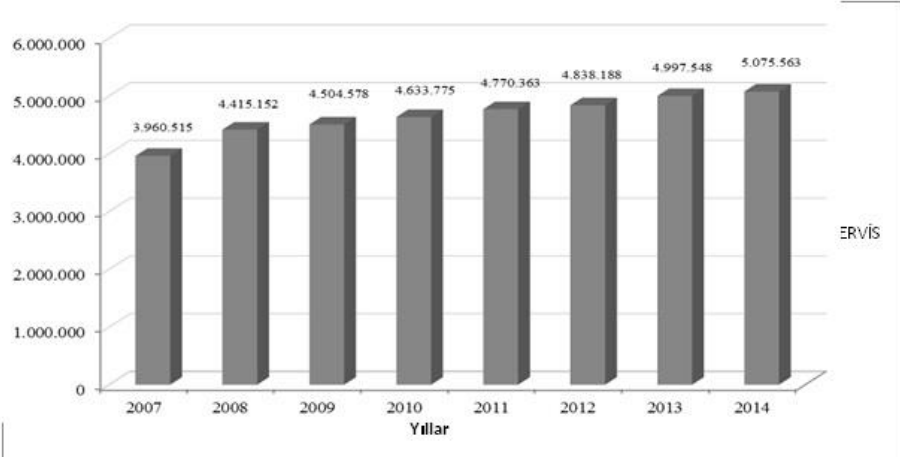

Şekil 1: Yıllara göre kliniklerin başvuru sayılarındaki değişim.

Aile hekimi; kişiye yönelik koruyucu sağlık hizmetleri ile birinci basamak teşhis, tedavi ve rehabilite edici sağlık hizmetlerini yaş, cinsiyet ve hastalık ayrımı yapmaksızın, her kişiye kapsamlı ve devamlı olarak belirli bir mekânda vermekle yükümlü, gerektiği ölçüde gezici sağlık hizmeti veren ve tam gün esasına göre çalışan aile hekimliği uzmanı veya kurumun öngördüğü eğitimleri alan uzman tabip veya tabipleri ifade eder [5]. Bu tanım çerçevesinde birinci basamak sağlık hizmeti veren hekimlerin hastayı bir bütün olarak ele alabilecek, hastayı çok yönlü değerlendirebilecek ve ihtiyaç halinde ikinci ve üçüncü basamak sağlık birimlerine yönlendirmesini yapabilecek donanım ve yetkiye sahip olması gerektiği düşünülmektedir.

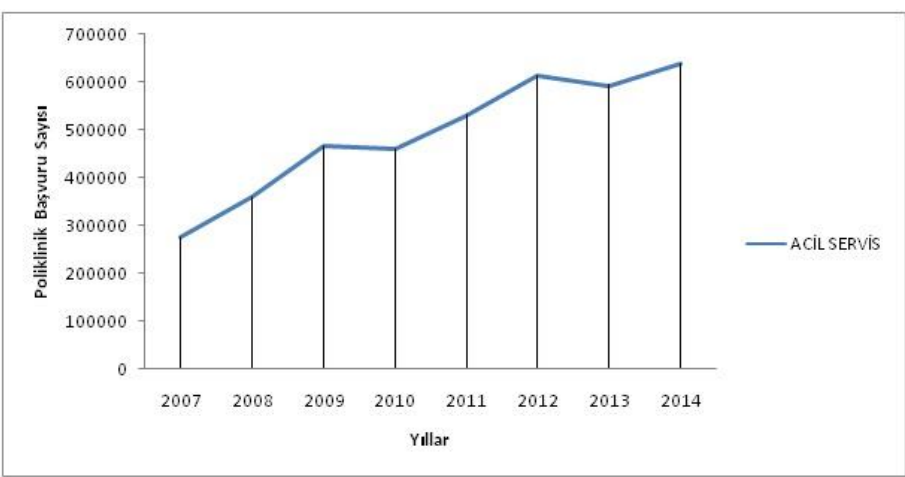

Şekil 2: Yillara göre acil servis başvuru sayılarındaki değişim.

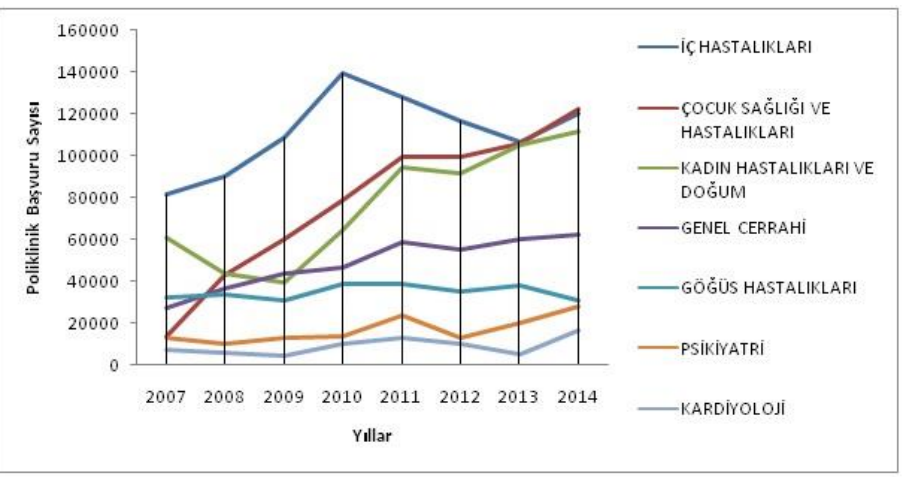

Şekil 3: İstanbul Anadolu yakası nüfusu (x: yıllar, y: nüfus).
Aile hekimliği uygulamasından yeterli verim alınabildiğinde ikinci ve üçüncü basamak sağlı hizmetlerinin hasta yoğunluğundan kaynaklı problemlerinin rahatlaması beklenmektedir [6]. Çalışmamızda aile hekimliği uygulamasının üçüncü basamak sağlık hizmeti veren bir Eğitim ve Araştırma Hastanesi'nin ayaktan hasta başvuru sayılarına etkisini değerlendirdik. AHU'ya İstanbul ilinde 30.10.2010 tarihinde geçilmiş olup takip eden iki aylık süreç geçiş aşaması olarak değerlendirmeye alındı. $\mathrm{Bu}$ yüzden 2011 yılının başlangıcı uygulama başlangıcı olarak kabul edildi.

Sağlık Bakanlığı tarafından aile hekimliği uzmanlık eğitiminde zorunlu alınması gereken klinik rotasyonlar ve süreleri belirlenmiştir [7]. Çalışmamızda bu rotasyon branşlarını ele almamızın sebebi; birinci basamak sağlık hizmetlerinde bu branş hastalarının daha yoğun olarak görüldüğünü ve ilerleyen dönemlerde aile hekimliği uzmanlarımızın bu branşlarda etkin donanıma sahip olmalarıyla birlikte birinci basamak sağlık hizmetleri kalitesinde anlamlı bir artış yaşanacağını düşünmemizdir.

Birinci basamaktaki uygulamanın güçlendirilmesi ile tüm gereksinimlere yanıt veren, yüksek nitelikli ve maliyet etkili bir sağlık sistemi hedeflenmektedir [8]. Üstü ve arkadaşlarının [9] yaptığı çalışmada Erzurum sağlık bölgesinde 2002 - 2008 yılları arası verileri sunulmuştur. Bu çalışmada birinci basamak başvurularında artış ve sevk oranlarında düşüş saptanmış olup AHU desteklenmiştir. Aile hekimliği farklı klinik tabloların uğrak yeri olabilmektedir. Aile hekimliğine başvurular en sık iç hastalıkları ile ilgili hastalıklar nedeni ile olmaktadır ve aile hekimleri bu konuda tedavi ve takipte önemli yer almaktadır [10]. Çalışmamızda AHU öncesi dönem ile sonrası dönem karşılaştırıldığında iç hastalıkları kliniğine başvuru sayıları ile nüfus artışı arasında anlamlı bir ilişki görülmemiş ve nüfus artmasına rağmen aynı oranda başvuran hasta sayısı artmamıştır. Ancak grafiksel değerlendirmede uygulamanın başlangıcını takip eden bir yıl içerisinde başvurularda belirgin bir azalma olduğu, sonraki yıllarda ise bu azalmayı bir artışın takip ettiği görülmektedir. Düşüşün sebebinin; iç hastalıkları kliniğine birinci basamak sağlık hizmeti almak için başvuran hastaların sağlı hizmetlerini aile hekimlerinin devralması olduğunu düşünebiliriz. Fakat son yıldaki artışı yorumlamak zor olmakla birlikte; aile hekimliği uygulamasının mevcut şartlar altında hastalar tarafindan yeterli bulunmadığı ve yeniden bir geriye dönüş yaşandığı izlenimi doğmaktadır.

Şensoy ve arkadaşlarının yaptığı bir çalışmada 20022004 yılları arasında aile hekimliği merkezine başvurular incelenmiş ve en sık değerlendirilen tanı üst solunum yolu enfeksiyonu olarak değerlendirilmiştir [11]. Çalışmamızda AHU öncesi ve sonrasında göğüs hastalıkları poliklinik başvuru sayılarındaki değişiklikler nüfusla bağıntıgöstermemekte, istatistiki olarak nüfus arttığı halde başvuran hasta sayısı artmamaktadır. Üst solunum yolu enfeksiyonları başta olmak üzere yaygın akut hastaların aile hekimlerine başvurarak buralarda tutulabilmesi bu sonucu doğurmuş olabilir. Fakat Atadağ ve arkadaşlarının yaptığı bir çalışmada aynı tanı grubu konulan hasta sayısının üçüncü basamak devlet hastanelerinde de artış gösterdiği görülmüştür[12]. Bu durum ise sağllk hizmetlerine erişimin kolaylaşmasının sonucu olabilir.

Genel cerrahi kliniğinin başvuru sayıları ise nüfusla bağıntıgöstermekte, nüfus artışıla birlikte istatistiki açıdan aynı oranda artış göstermektedir. Dolayısıyla aile hekimliği uygulamasının genel cerrahi poliklinik başvuru sayılarına anlamlı bir etkisinin olmadığını görmekteyiz. Bu bağlamda aile hekimlerinin bu branş üzerine eğitimlerine ağırlık verilmesi, hastaların başvuru noktasında gerek kamu spotlarıyla gerek çeşitli ilanlarla bilgilendirilmeleri gerektiğini düşünmekteyiz. 
Durusoy ve arkadaşlarının İzmir ilinde yaptığı, ikinci ve üçüncü basamak hastanelere başvuran gebelerin incelendiği çalışmanın sonucunda; kadınların gebe olduğunu öğrendikten sonra ilk kontrol için aile hekimlerine gitmek yerine devlet hastanelerini tercih ettikleri görülmüştür [13]. Çalışmamızda kadın hastalıkları ve doğum klinik başvurularına baktığımızda, uygulama öncesi ve sonrası dönem başvuru sayıları nüfusla korelasyon göstermekte, hatta sayısal olarak anlamlı bir artış göstermektedir. Bu etkinin ana çocuk sağlığı görevinin sınırlı sayıda ana çocuk sağlı̆̆ ve aile planlama merkezleriyle yürütülmekten öte yaygın olarak aile sağlığı merkezlerinin etkin bir rol üstlenmeye başladığının, özellikle gebelerin daha iyi takip edildiğinin ve gereği halinde bir üst basamağa yönlendirildiğinin bir göstergesi olduğunu düşünmekteyiz. Bu bağlamda, ikinciveya üçüncü basamakta müdahale gerektirmeyen durumlarda gebe izlemlerinin tamamen aile hekimleri tarafindan yapılması sağlanmalıdır.

AHU içinde aile planlaması hizmetleri, ana çocuk sağlığ1 ve aşılama hizmetleri gibi geniş kapsamlı görevler bulunmaktadır. Nesanır ve arkadaşlarının 2010 yılında yaptığ bir çalışmada AHU'ya geçen 11 il değerlendirilmiş ve sonuç olarak uygulamanın umut vaat edici olduğu konusunda fikir birliğine varılmıştır [14]. Çalışmamızda çocuk sağlığı ve hastalıkları kliniğini incelediğimizde, uygulama sonrası başvuru sayılarında uygulama öncesine göre istatistiki olarak anlamlı bir artış veya azalış olmamakla birlikte grafiksel değerlendirmede artış hızında bir yavaşlama olduğunu görüyoruz. $\mathrm{Bu}$ etkinin daha da arttırılabilmesi için ailelerin bu konuda daha iyi yönlendirilmesi ve bilgilendirilmesi gerektiğini, öncelikle birinci basamak sağlık hizmetlerinin tercih edilmesi noktasında teşvik edilmesi gerektiğini ve aile hekimlerimizin çocuk sağlığ ve hastalıkları üzerine eğitimlerine ağırlık verilmesi gerektiğini düşünmekteyiz.

Ruh sağlığı ve hastalıkları kliniği başvuru oranlarında uygulama öncesi dönem ile sonrası dönem karşılaştırıldığında istatistiki olarak anlamlı bir değişiklik olmadığı görülmektedir. Süreç takip edildiğinde uygulama sonrası bir yıllık sürede başvuru oranlarında diğer yıllara göre anlamlı bir artış, takip eden yıl içerisinde ise tekrar anlamlı bir azalma görmekteyiz. Genel olarak baktığımızda başvuru oranındaki en düşük değer uygulama sonrası ikinci yıldır. Ruh sağlığı ve hastalıkları kliniğine o yıl içinde başvuruyu artıran diğer faktörleri araştırmadan bir yargıya varmak mümkün değildir. Bu branş için değerlendirmenin elimizdeki kısa süreli verilerle sağlıklı yapılamayacağını, daha geniş bir süreç ele alınarak detaylı değerlendirilmesinin daha uygun olacağını düşünüyoruz.

Kardiyoloji kliniği başvuru oranlarının uygulama öncesi dönem ile sonrası dönem karşılaştırıldığında istatistiki olarak nüfus artışıyla bağıntılı bir artış izlenmemektedir. Grafiksel değerlendirmesinde ise uygulama sonrasındaki bir yıl içinde artış hızında belirgin bir azalma, takip eden yıl içindeyse başvuru oranında düşüş olduğunu görüyoruz. İlk etapta istatistiki olarak başvuru sayılarında bir düşüş olduğu düşünülebilir. Fakat hastanemizde kardiyoloji yataklı servisi olmaması ve mevcut hekimlerin sadece ayaktan hasta hizmeti verdiğini göz önünde bulundurursak uygulama sonrası başvuru oranındaki azalmayı uygulamanın etkisi olarak görmenin sağlıklı bir tespit olmayacağını düşünüyoruz. Ayrıca hastanemizde sadece ayaktan hasta kabul ediliyor olması, bu hastalar içinde birinci basamak hastalarının oranının oldukça yüksek olmasını mümkün kılmaktadır.

Başak ve arkadaşları tarafından 2014 yılında yapılan bir çalışmada aile hekimliği bölümlerinin 20 yıl içindeki gelişim süreci incelenmiş ve sonuç olarak aile hekimliği bölümlerinin nicel ve nitel gelişimi, Avrupa'da birçok ülkeyle kıyaslanabilir düzeyde olduğu ifade edilmiştir [15]. Yine 2014 yılında Baykan ve arkadaşlarının yaptığı çalışmada tükenmişlik durumları incelenmiş ve sonuç olarak aile hekimlerinin büyük bir kısmı, mevcut uygulamanın hekimler arasındaki rekabeti, iş yükünü ve stresini, etik yozlaşmayı artırdığını; yarısı sosyal hayatlarına ve mesleki gelişimlerine ayırdıkları zamanı azalttığını ifade etmişlerdir [16].

Atun ve arkadaşları sağlıkta dönüşüm programı ile birinci basamak sağlık hizmetlerinin kapsamının genişlediğini vurgulamışlardır. Yazarlara göre, bağışıklama, ana çocuk sağlığ hizmetleri kapsamlarında genişleme ve ilk başvuru, tanı, tedavi ve izlem oranlarında artış gözlemlenmiştir [17]. Buna karşılık hizmet verenlerin görüşleri alındığında Aile Sağlığı Merkezi ve Toplum Sağlığı Merkezi hekimleri gebe, bebek izlemi ve bağışıklama hizmetlerinin iyi bir düzeyde yürütüldüğünü belirtmekle beraber bu hizmetlerin sağlık ocağı sisteminde de zaten iyi olduğunu ve önemli bir değişim gerçekleşmediğini ifade etmişlerdir. Birinci basamak sağlık çalışanları negatif performans uygulanmasaydı izlem oranlarının bu kadar yüksek olamayacağını düşünmektedirler. Ayrıca kronik hastalıklara yönelik hizmetlerin yetersiz düzeyde olduğunu ya da sağlı ocağı dönemine göre hiçbir gelişme göstermediği dile getirilmiştir [18].

Çalışmamızda tespit edilen veriler ışığı altında birinci basamak sağlık hizmeti veren aile sağlığı merkezleri ve toplum sağlığı merkezlerinin uygulama sonrası üçüncü basamak hastaneler üzerinde başlangıç için olumlu fakat oldukça sınırlı etkiler oluşturduğunu söyleyebiliriz. Hastaların doğrudan aile hekimlerini tercih etmesini özendirici tedbirlerin alınması ve özellikle çocuk sağlığı ve hastalıkları ile kadın hastalıkları ve doğum gibi branşlarda aile hekimlerin eğitiminin artırılması gerektiğini düşünüyoruz. Ayrıca aile hekimliği eğitiminde yeterli nicel ve nitel eğitimin uygulanmasının yanında aile hekimlerinde tükenmişlik durumlarının önlenmesi konusunda uygulamalar geliştirilmelidir.

Aile hekimliği uygulamasının en zayıf noktası sevk zincirinin olmamasıdır. Sevk zinciri olmadan etkili ve maliyet etkin birinci basamak sağlık hizmetlerinden bahsedilemez. Aile hekimlerinin sağlık sisteminin ana giriş kapısı olması beklenir. Sevk zinciri olmadığında aile hekiminin sağlık hizmetinin koordinasyonunu tam olarak sağlaması güçtür. Kringos'un çalışmasında birinci basamağın hastalar tarafından tercih edilme oranının, sevk zinciri gibi zorunlu bir uygulama olmadıkça, yıllar içerisinde değişmeden nasıl sabit bir seyir izlediği gösterilmiştir. Uygulama özellikleri itibarıyla Türkiye'nin birinci basamak sağlık hizmet sunumunun zayıf kategorisinde yer almasına neden olan önemli etkenlerden birisi koordinasyon işlevini yerine getirememesidir [8].

Aile hekimleri sevk zinciri uygulanmamasının getirdiği olumsuzluklar arasında özellikle kronik hastalıklar açısından ilk başvuru fonksiyonunun gerçekleştirilememesini de saymışlardır. Bununla birlikte aynı aile hekimlerinin mevcut koşullarda birinci basamağa sevk uygulaması getirilmesinin son derece olumsuz sonuçlara yol açacağını düşünmeleri dikkat çekicidir. Bu noktada temel kaygı iş yükünün aşırı artışı olarak ifade edilmiştir [19].

Katı bir sevk zincirinin tam olarak gerçekleştiği örnekler dünyada yok denecek kadar azdır. Bugünkü sağlık sistemi alt yapımızla başarılı bir sevk zincirinin uygulamaya alınmasında zorluklar görülmektedir. Bu durumun nedeni olarak; "Birinci basamak sağlı hizmetlerinde görevli hekim sayısı ikinci ve üçüncü basamak sağlık hizmetlerinde görevli hekim sayısının yaklaşık dörtte biridir" şeklinde ifade edilmiştir. Sevk zincirinin uygulamaya alınabilmesi için bu oranın tersine çevirilmesi gerektiği öngörülmüştür. Birinci basamak sağlık hizmetlerini yürüten aile hekimliği birimlerinin donanım olarak zenginleştirilmesi, halkın buralara yönlendirilmesi ve tasarlanan hizmete yeter hale getirilmeleri gerekmektedir [20]. 
Aile hekimliği uygulamasının başlangıç olarak olumlu fakat sınırlı etkiler oluşturduğu görülmektedir. Bu etkinin daha da arttırılabilmesi için hastaların başvuru noktası konusunda belli aralıklarla detaylı bilgilendirilmesi, aile hekimlerine başvurmaları için teşvik edilmesi ve gerekli yasal düzenlemelerin yapılması gerekmektedir. $\mathrm{Bu}$ bağlamda optimal alt yap1 oluşturulup, yeterli sayıda birinci basamak sağlık elemanı ile sağlıkta sevk zincirinin uygulamaya alınmasının birinci basamak sağlık hizmetlerinin değerini arttıracağını, ikinci ve üçüncü basamak sağlık hizmeti veren kurumlardaki hasta yoğunluğunu azaltacağını ve hastaların daha kaliteli sağlık hizmeti alabileceğini düşünüyoruz.

\section{Kaynakça}

1. Kırşehir Sağlık Müdürlüğü, Aile Hekimliğinin Amaç ve Hedefleri http://www.kirsehirsaglik.gov.tr/ailehekimligi/giris.asp?s=icerik_detay\& id=1. Alıntı tarihi: 27.01.2016

2. Yalova İl Sağlık Müdürlüğü, Aile Hekimliğinde Amaç ve Hedefler. http://yalovasaglik.gov.tr/Icerik/IcerikDetay.aspx?IcerikID=33 Alınt1 tarihi: 27.01 .2016

3. Aile Hekimliği Türkiye Modeli. Mavi Ofset. Ankara, 2004

4. Aile Hekimliği Uygulama Yönetmeliği; Resmi Gazete Tarihi: 25.01.2013 Resmi Gazete Say1s1: 28539

5. Aile Hekimliği Kanunu. Resmi gazete Sayı:25665, 2004.

6. WONCA Europe 2002, The European Definition of General Practice/Family Medicine.

7. Sağlık Bakanlığı, Tipta Uzmanlık Kurulu, 23/06/2010 tarih ve 82 sayılı Karar.

8. Kringos DS. The Importance of Measuring And İmproving The Strength Of Primary Care İn Europe: Results Of An İnternational Comparative Study. Türk Aile Hek Derg 2013;17:165-79.

9. Üstü Y, Uğurlu M, Örnek M, Sanisoğlu SY. 2002-2008 Yılları Arasında Erzurum Bölgesinde Birinci ve İkinci Basamak Sağlk Hizmetlerinin Değerlendirilmesi. Balkan Med J 2011;28:55-61.

10. Ertürk NT, Süt N, Sipahioğlu F. Cerrahpaşa Tip Fakültesi Aile Hekimliği Polikliniğine Başvuran Hastaların 3 Yıllık Profili. Cerrahpaşa J Med 2004; 35: 115-21.

11. Şensoy N, Başak O, Gemalmaz A. Umurlu Aile Hekimliği Merkezi'nde Ahuve Hasta Profili: Aile Hekimliği Alan Eğitimi Gereksinimini Ne Ölçüde Karşılıyor? MedJKocatepe 2009;10:49-56.

12. Atadă Y, Aydın A, Kaya D,Köşker HD, Başak F, Uçak S. Aile Hekimliği Uygulamasıyla Üçüncü Basamak Sağlı Kuruluşuna Başvuru Sebeplerinde Olan Değişiklikler. Türk Aile Hek Derg 2016;20: 141-51.

13. Durusoy R, Davas A, Ergin I, Hassoy H, Tanık FA. Prenatal Care Utilization From Family Physicians: A Study Among Pregnant Women Applying To Secondary And Tertiary Care Hospitals İn Izmir. Turk J Public Health 2011;9:1-15.

14. Nesanır N, Erkman N. Aile Hekimliği Uygulamasına Geçen İlk 11 İlin Sağlık Göstergeleri Üzerinden Bu Sürece Bir Bakış. TAF Prev Med Bull 2010;9:493-504.

15. Başak O, Güldal D. Akademik Aile Hekimliği Bölümlerinin 20 yılı: Gelişimsel Süreç Üzerine Bir Değerlendirme. Türk Aile Hek Derg 2014;18:16-24.

16. Baykan Z, Çetinkaya F, Naçar M, Kaya A, Işıldak MÜ. Aile Hekimlerinin Tükenmişlik Durumları ve İlişkili Faktörler. Türk Aile Hek Derg 2014; 18:122-33.

17. Atun R, Aydin S, Chakraborty $S$ et al. Universal Health Coverage in Turkey: Enhancement of Equity. The Lancet 2013;382:65-99.

18. Kringos DS, Boerma W, Bourgueil Y et al. The Strength of Primary Care in Europe: an International Comparative Study. Br J Gen Pract 2013;63:e742-50.

19. Öcek Z, Çiçeklioğlu M. Aile Hekimliği Birinci Basamak Sağlık Ortamını Nasıl Dönüştürdü? Türk Tabipler Birliği Yayınları. Ankara.2013.

20. http://www.ivek.org.tr/-medipol-universitesi-rektoru-prof.-dr.sabahattin-aydin-ile-kahvalti-1426h.htm) Alıntı tarihi: 27.01.2016. 